\title{
Bacterioplankton growth associated with physical fronts during a cyanobacterial bloom
}

\author{
Anne Heinänen, Kaisa Kononen, Harri Kuosa, Jorma Kuparinen, Kalervo Mäkelä
}

Finnish Institue of Marine Research, PO Box 33, FIN-00931 Helsinki, Finland

\begin{abstract}
The main compartments of the microbial food web were studied in a hydrodynamically complicated area to determine the response of bacterioplankton to spatio-temporal discontinuities in the water column structure. The samples were divided according to water masses into those representing frontal areas and those representing low-saline areas. In the upper mixed water layer (UML) bacterial production was higher in the frontal water (average $4.5 \mathrm{mg} \mathrm{C} \mathrm{m}^{-3} \mathrm{~d}^{-1}$ ) than in the low-saline water $\left(3.7 \mathrm{mg} \mathrm{C} \mathrm{m}^{-3} \mathrm{~d}^{-1}\right)$. However, the proportion of bacterial production of the primary production was about the same in the frontal water $(15 \%)$ and in the low-saline $(16 \%)$ water. The data implied that the recorded frontal upwelling event did not drastically change the mode of production from regenerated to new production. Furthermore, the data indicated that heterotrophic flagellates did not respond to increased bacterial abundance during the intervals between hydrodynamic events. Below the thermocline, the turnover time of bacterial numbers was less than in the UML, as was thymidine incorporation (TdR) per cell, but leucine incorporation (Leu) per cell was highest in the UML. The average molar ratio of Leu to TdR was 7.7 in the UML and 3 below the thermocline. The molar ratio showed an increase in the growth rate during a storm event. Leu and TdR methods did not give equivalent rates of bacterial production over the daily timescale, although they gave quite similar estimates when averaged over the whole study period (11 d). Our data indicated that one should be very cautious in using conversion factors, which are derived from surface water, to calculate bacterial production throughout the water column, and that sometimes even higher conversion factors should be used below the thermocline than in the UML.
\end{abstract}

KEY WORDS: Bacterioplankton - Bacterial production - Thymidine incorporation - Leucine incorporation $\cdot$ Heterotrophic flagellates $\cdot$ Picocyanobacteria $\cdot$ Cyanobacteria $\cdot$ Physical fronts $\cdot$ Baltic Sea

\section{INTRODUCTION}

The central role of heterotrophic bacterioplankton in the carbon flow of aquatic food webs has been established during the past decade (Williams 1981, Azam et al. 1983). Several experimental studies have provided valuable information on the factors limiting and regulating bacterioplankton growth in controlled environments with a limited set of manipulated factors (e.g. Wright \& Coffin 1984, Goldman et al, 1987, Autio 1990 , Kirchman et al. 1990, Kuuppo-Leinikki 1990, Kivi et al. 1993, Kuparinen \& Heinänen 1993, Zweifel et al. 1993, Shiah \& Ducklow 1994). Extrapolation of the results from controlled, laboratory-scale studies to natural environments on ocean and global scales seems to be the challenge in this decade. This extrapolation from flasks to oceans not only requires field studies upscaled to different spatio-temporal scales, but also interdisciplinary studies, with biological, chemical and physical interactions. However, such interdisciplinary studies are sparse in the literature (Kiørboe 1993) mainly due to the difficulty in simultaneously covering all the spatio-temporal scales involved in the dynamics of pelagic physics and biology (McManus \& Fuhrman 1988).

In temperate sea areas, such as the Baltic Sea, plankton community dynamics are predominantly influenced by season (Hällfors \& Niemi 1986). The main features in the northern Baltic Sea proper are the spring and summer blooms. In our study area, at the entrance to the Gulf of Finland, the vigorous phytoplankton spring bloom ends in the depletion of in- 
organic nutrients and the stratification of the water column. The major part of the phytoplankton spring bloom ('new production' sensu Dugdale \& Goering $1967)$ is removed from the pelagic food webs through sedimentation (Leppänen 1988, Lignell et al. 1993). In summer, the water column is steeply temperature stratified and the thermocline and the nutricline coincide (Stigebrandt \& Wulff 1987). Phytoplankton production, based mainly on regenerated nutrients, occurs in the upper mixed water layer (10 to $20 \mathrm{~m}$ deep) isolated from the nutrient reserves, and the microbial loop type food web prevails. However, occasional events, e.g. upwelling and storms, may break the stratification during summer and bring mineral nutrients into the photic layer. Thus, spatio-temporally, new production may interfere with the regenerated mode of production.

The response of bacterioplankton to spatio-temporal discontinuities in water column structure has been poorly investigated. It has been shown experimentally that, during the new production period in the study area (spring phytoplankton bloom), bacterioplankton is mainly controlled by the availability of labile DOC (dissolved organic carbon) (bottom-up). The control by predators (top-down) is of minor importance, because bacterioplankton growth rates are faster at low temperatures than those of their predators. During the regenerated production period (stratified summer situation), both nutrient and predator control are important (Kivi et al. 1993, Kuparinen \& Heinänen 1993).

The Baltic Sea is a hydrodynamically complicated sea area due to the shallow and complex bottom topography, remarkable salinity gradients (from almost limnic in the bayheads to ca $8 \mathrm{ppt}$ in the open Baltic Sea) and periodic water exchange with the North Sea. Compared to the oceans, the spatial and temporal scales of hydrodynamic events and features are small, e.g. upwelling and wind-induced mixing occur over a time scale from hours to a few days and the spatial scale of hydrodynamic fronts is only kilometres (Nômmann 1990). The deepening or even break-up and renewal of the thermocline may occur on a scale of hours during a storm (Krauss 1981, Mälkki \& Tamsalu 1985). As the thermocline and nutricline are coincident in the Baltic Sea during summer, the total amount of nutrients available to the pelagic food webs is occasionally enhanced by disruptions in the vertical structure of the water column. It can be hypothesised that, during such occasions, the microbial food web will be forced out of balance, different components of the microbial food web being able to grow under less control by nutrients and/or predators. Recording of such events requires a sampling strategy which is in accordance with the phenomena under study.

In this paper, the dynamics of the main compartments of the microbial food web (bacterioplankton, heterotrophic flagellates and picocyanobacteria) were studied in the upper mixed water layer during a cyanobacterial bloom in August 1992. The special focus is on bacterioplankton; and, the problems arising in bacterial production measurements in a hydrodynamically complicated area are discussed in detail.

\section{MATERIALS AND METHODS}

Study area. The study area extended from the Finnish coast to the Estonian coast, across the entrance to the Gulf of Finland (Fig. 1). The observation window for the study was restricted to an area where the inclination of the sea bottom, from depths more than $100 \mathrm{~m}$ to ca $30 \mathrm{~m}$ towards the coasts and to ca $70 \mathrm{~m}$ towards the inlet to the gulf, forms a gradually shallowing groove-like slope structure. Earlier studies (Kahru et al. 1986) revealed the existence of a quasi-persistent salinity front in the area. It has also been shown that hydrodynamic processes related to the bottom topography and the specific frontal system of the area are clearly reflected in the phytoplankton bloom dynamics (Kahru et al. 1986, Kononen \& Nômmann 1992, Nômmann \& Kaasik 1992).

The depth of the upper mixed layer (UML) varied at Stn GR9 from 7 to $20 \mathrm{~m}$, at Stn GR10A from 10 to $18 \mathrm{~m}$, at Stn GR8 from 8 to $24 \mathrm{~m}$ and at Stn GR7 from 7 to $18 \mathrm{~m}$. Three water masses of different origin were observed in the UML of the study area: (1) water of the Gulf of Finland (GOF) (salinity 5.7 to $6.1 \mathrm{ppt}$, relatively colder),

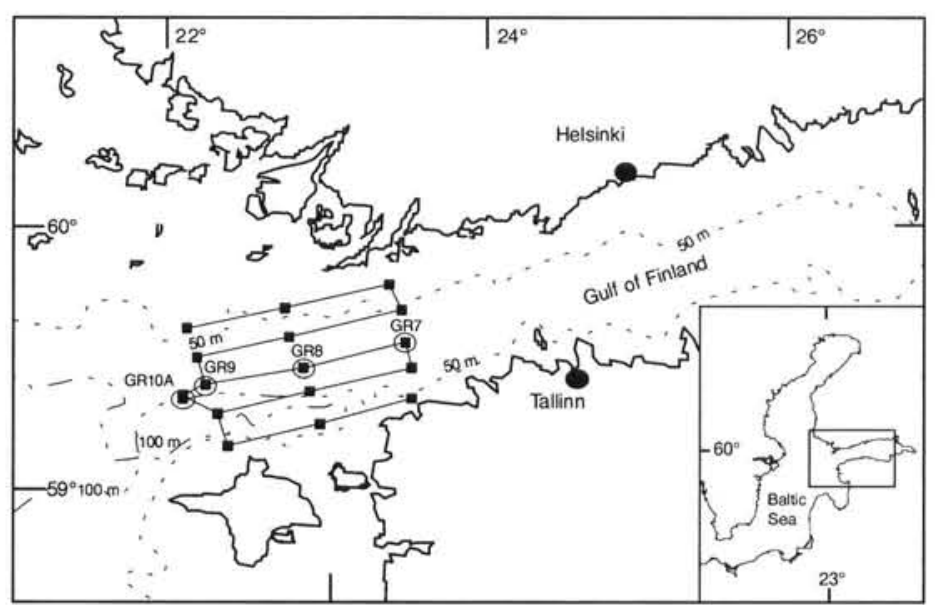

Fig. 1. Locations of the fixed sampling stations and grid in the study area, August 1992. (0) Stns GR10A, GR9, GR8 and GR7, where biological samples were taken; (四) stations where nutrients were analysed, the sampling grid is denoted as a solid line between the stations 
(2) water of the Northern Baltic Proper (NBP) (salinity 6.4 to $6.6 \mathrm{ppt}$, relatively warmer), and (3) upwelled water $\left(13\right.$ to $15^{\circ} \mathrm{C}$ ). In the thermocline layer, the location of the internal frontal interface between GOF water and NBP water did not vertically match with the surface front. In the intermediate water layer between the thermocline and the halocline, the internal front was persistently located between Stns GR10A and GR9. At Stn GR8, a body of NBP water inside the less-saline water mass was moving slowly towards the west in the intermediate layer. In the halocline, the distribution of water masses was similar to that in the intermediate water layer.

At the beginning of the research cruise, the average wind was NE at ca $10 \mathrm{~m} \mathrm{~s}^{-1}$ for $1 \mathrm{wk}$ and, after a 2 to $3 \mathrm{~d}$ period of calm, southerly winds, wind speed increased to $15 \mathrm{~m} \mathrm{~s}^{-1}$ (on 11 August). During the storm the wind was E, but the next day (12 August) it was again SW. Upwelling at the northern (Finnish) coast and downwelling at the southern (Estonian) coast caused by the persistent SW wind took place between 4 and 11 August. Clear salinity fronts existed inside our observation window from 14 July to 17 August according to the high-resolution automatic surface layer salinity measurements made daily on board a ferry which sailed regularly across our study area. The appearance and location of any particular front, however, varied (Eija Rantajärvi \& Juha-Markku Leppänen, Finnish Inst. Mar. Res., unpubl. data). During our cruise, the quasi-permanent surface salinity front between the 2 main water masses was characterised as follows: the salinity difference between the 2 sides was 0.3 to $0.5 \mathrm{ppt}$, temperature difference was 0.2 to $0.3^{\circ} \mathrm{C}$, the front was generally east-west directed and relatively stationary in space and time (e.g. Fig. 3).

Sampling. A single integrated sample to represent the whole UML was prepared as follows. Density and chlorophyll profiles were used to determine the depth of the UML. Water samples were taken at $1 \mathrm{~m}$ intervals from the UML and mixed in a container. Between 5 and 101 of water were taken from each sampling depth. In addition, at Stn GR9 and later at Stn GR10A, bacterioplankton analyses were also done from vertical samples at depths of $0,20,40,60$ and $90 \mathrm{~m}$. The sampling at fixed locations was done daily, 3 to 13 August 1992, at 3 stations (Fig. 1). The westernmost station was moved towards the west (GR10A instead of GR9) during the course of the study as the water masses moved. In the analysis of data, the samples were divided according to water masses into those representing the frontal area and into those representing the low-salinity area (Table 1). The water mass at Stn GR7 on 11 to 13 August was apparently different from the 2 known water masses, but it was impossible to locate its origin inside our observation window. These data are shown in the figures, but was excluded
Table 1. The location of sampling stations in different water masses during the study period

\begin{tabular}{|lclc|}
\hline Station & Frontal & $\begin{array}{l}\text { Water mass } \\
\text { Low-saline }\end{array}$ & Unknown \\
\hline GR7 & & $3-10$ Aug & 11-13 Aug \\
GR8 & 12-13 Aug & 3-11 Aug & \\
GR9 & 3-7 Aug & 8-10 Aug & \\
GR10A & 11-13 Aug & & \\
\hline
\end{tabular}

from the data analyses, although including this data in the data set of frontal samples would not have caused any major changes in the results.

Nutrients were analysed daily at 12 extra fixed grid stations, normally at $10 \mathrm{~m}$ intervals from surface to bottom, unless more frequent sampling was necessary. In addition, 24 CTD measurements were made at 21 fixed grid stations and chlorophyll (in situ fluorescence), salinity and temperature at $5 \mathrm{~m}$ depth within the observation window were measured semi-continuously on board RV 'Aranda' during 2 to 14 August (Fig. 1).

Bacterial numbers. Subsamples $(20 \mathrm{ml})$ were fixed with filtered ( $0.2 \mu \mathrm{m}$ Minisart filters, Sartorius) formalin $(200 \mu \mathrm{l}, 39 \%)$, stained with filtered $(0.2 \mu \mathrm{m}$ Minisart filters, Sartorius) acridine orange $(0.5 \mathrm{mM})$, filtered onto Nuclepore filters (polycarbonate, black, $0.2 \mu \mathrm{m}$ ), and the numbers of bacteria were enumerated under an epifluorescence microscope (Hobbie et al. 1977). The counting was made with a Leitz Aristoplan microscope using $12.5 \times$ oculars and a PL Fluotar $100 \times / 1.32$ oil objective. At least 200 cells and 20 fields were counted from each preparation.

Turnover time of bacterial numbers (days) was calculated by dividing the cell numbers by the cell production rate measured by thymidine incorporation using a conversion factor of $1.1 \times 10^{18} \mathrm{cells} \mathrm{mol}^{-1}$ (Riemann et al. 1987).

Thymidine and leucine incorporation. Duplicate subsamples $(10 \mathrm{ml})$ and 1 formalin-killed control from each sample were incubated in acid-washed glass vials with a saturating concentration of 10 to $12 \mathrm{nM}$ [methyl- ${ }^{3} \mathrm{H}$ ] thymidine (48 to $51 \mathrm{Ci} \mathrm{mmol}^{-1}$; Amersham International, Amersham, UK) for 39 to $143 \mathrm{~min}$ (Fuhrman \& Azam 1982, Heinänen 1993). Duplicate subsamples $(10 \mathrm{ml})$ and 1 formalin-killed control were also incubated with L-[4,5- $\left.{ }^{3} \mathrm{H}\right]$ leucine (135 to $166 \mathrm{Ci}$ $\mathrm{mmol}^{-1}$; Amersham International) for 55 to $112 \mathrm{~min}$. The final concentration of leucine was 102 to $104 \mathrm{nM}$ (100 nM unlabelled leucine) (Kirchman et al. 1986). The measurement of leucine incorporation was carried out on the vertical samples at Stns GR9 and GR10A. The ambient saturation levels of thymidine and of leucine were measured during the cruise: for thymidine it was about $10 \mathrm{nM}$ and for leucine 40 to $100 \mathrm{nM}$. 
The incubations were carried out at in situ temperature and stopped by adding $100 \mu \mathrm{l}$ of formalin. The subsamples were filtered through $0.2 \mu \mathrm{m}$ cellulose nitrate filters (Sartorius). The incubation vials, filtration funnels and filters were rinsed with ice-cold 5\% TCA. Filtration equipment and samples were kept ice cold throughout the filtration procedure. Radioactivity counting was performed on board RV 'Aranda' using a 1219 Rackbeta liquid scintillation counter (LKB Wallac, Turku, Finland) after adding $10 \mathrm{ml}$ of scintillator (Lumagel, Lumac) to each sample.

Bacterial production. The calculation of bacterial production based on the thymidine incorporation rate was done using a conversion factor of $1.1 \times 10^{18}$ cells $\mathrm{mol}^{-1}$ (Riemann et al. 1987), a carbon content of $0.35 \mathrm{pg}$ $\mathrm{C} \mu \mathrm{m}^{-3}$ (Bjørnsen 1986) and a mean cell volume of $0.024 \mu^{3}$ based on Heinänen \& Kuparinen (1993) and data by Heinänen (unpubl.) from the study area. Bacterial production was calculated from the leucine incorporation rate according to Simon \& Azam (1989). We used a leucine concentration which was above the saturation level and therefore omitted the isotope dilution factor from the equation. The areal productivity values based on vertical sampling at Stns GR9 and GR10A were calculated using trapezoid integration.

Heterotrophic nanoflagellates. Heterotrophic flagellates were enumerated with epifluorescence microscopy. The samples were fixed with glutaraldehyde (EM grade) at a final concentration of $2 \%$. Of the sample, $5 \mathrm{ml}$ was then stained with proflavine for $1 \mathrm{~min}$ and filtered onto a black Nuclepore $0.2 \mu \mathrm{m}$ pore-sized polycarbonate filter (Haas 1982). The filters were mounted on paraffin oil and stored in a freezer until analysis. A Leitz Dialux microscope fitted with a HBO50 mercury lamp, Leitz filter block $\mathrm{I}_{2}$ and a $100 \times / 1.32$ oil immersion objective was used. At least 100 flagellates were counted from each sample.

Picocyanobacteria. Samples for counting of picoplanktonic cyanobacteria $(5 \mathrm{ml})$ were filtered onto black $0.2 \mu \mathrm{m}$ pore-sized Nuclepore filters under a vacuum less than $13 \mathrm{kPa}$. The samples were not fixed or stained. The filters were mounted in paraffin oil and examined with a Leitz Aristoplan microscope equipped with a $50 \mathrm{~W}$ mercury lamp. Cyanobacteria were enumerated with epifluorescence microscopy using green excitation light (Leitz filter set M2) and $100 \times / 1.32$ oil immersion objective. On an average 200 cells (minimum 100 cells) per filter were counted.

Phytoplankton primary production and chlorophyll a (chl a). Primary production estimates were based on simulated in situ measurements (Nielsen \& Bresta 1984) from the integrated water sample (surface to thermocline) incubated in the deck incubator. Water from the sampling depths was poured through a
$200 \mu \mathrm{m}$ mesh filter to remove larger zooplankton and aggregates. This integrated sample was further poured through $20 \mu \mathrm{m}$ mesh to obtain a $<20 \mu \mathrm{m}$ size fraction. The $<20 \mu \mathrm{m}$ fraction was further filtered by gravity through a $2.0 \mu \mathrm{m}$ Nuclepore filter $(45 \mathrm{~mm}$ diameter). From the $<2 \mu \mathrm{m}$ size fraction, triplicate $20 \mathrm{ml}$ aliquots were incubated in the deck incubator under surface light $(100 \%)$. From the $<20 \mu \mathrm{m}$ size fraction, duplicate $20 \mathrm{ml}$ aliquots were incubated under different light levels $(10,20,40,60,80,100$ and $110 \%$ of surface light). From the $<200 \mu \mathrm{m}$ size fraction, an additional $60 \mathrm{ml}$ aliquot was incubated under surface light. A larger volume sample from the $<200 \mu \mathrm{m}$ size fraction was used to obtain a more representative value for particulate production from the water which had observable aggregates.

Irradiance during the day and during the $2 \mathrm{~h}$ incubation period was recorded with a LI quantum sensor (LI-COR, Lincoln, NB, USA). Relative irradiance was recorded during each sampling from $0,1,2,3,4,5,10$, 15 and $20 \mathrm{~m}$ depths with the quantum sensor. In order to calculate daily production, a normalised photsynthesisirradiance (PI) curve was made from the measurements at different light levels in the incubator at noon (Fig. 2). From the measurements of surface irradiance during the day and the vertical irradiance attenuation at the sampling station, a matrix for actual irradiances for each hour could be constructed. Combining the actual irradiances and the relative production rates from the PI curve, a matrix of relative production for the whole day for the different light depths was established (Table 2). The actual production rates at different depths were obtained from the incubator measurements and the relative production data in the matrix. Daily production rates were calculated by summing the integrated (trapezoid) hourly depth profile values.

The chl a concentration was determined on Whatman GF/F glass fiber filters after extraction with $96 \%$

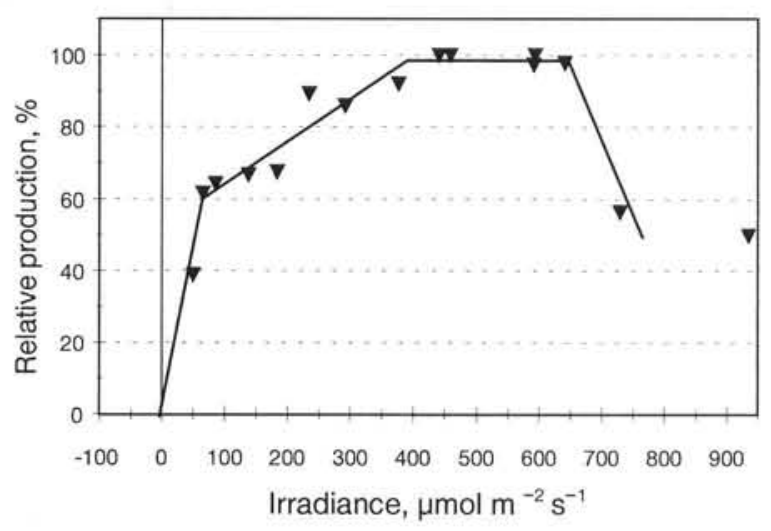

Fig. 2. A normalized PI curve made from the measurements at different light levels in the incubator at noon 
Table 2. A matrix of relative production for an entire day and for the different light depths based on light values on 2 Aug and actual irradiance measurements

\begin{tabular}{|c|c|c|c|c|c|c|c|c|c|c|c|c|c|c|}
\hline \multirow{2}{*}{$\begin{array}{l}\text { Depth } \\
\text { (m) }\end{array}$} & \multirow{2}{*}{$\begin{array}{l}\text { Relative } \\
\text { attenuation }\end{array}$} & \multicolumn{13}{|c|}{ Time of day (h) } \\
\hline & & $\begin{array}{l}8 \\
\dot{0} \\
\dot{0} \\
1 \\
8 \\
\dot{0} \\
0\end{array}$ & 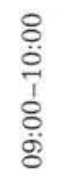 & $\begin{array}{l}\stackrel{8}{0} \\
\stackrel{-1}{1} \\
\\
0 \\
0\end{array}$ & 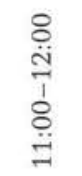 & 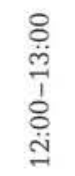 & 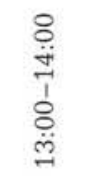 & 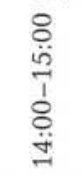 & $\begin{array}{l}8 \\
\ddot{0} \\
1 \\
\stackrel{0}{0} \\
\stackrel{\leftrightarrow}{3}\end{array}$ & $\begin{array}{l}\stackrel{8}{0} \\
\stackrel{\leftrightarrow}{1} \\
\stackrel{1}{0} \\
\dot{0}\end{array}$ & 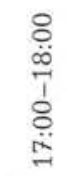 & $\begin{array}{l}8 \\
\dot{0} \\
1 \\
\\
\stackrel{0}{0} \\
\dot{0}\end{array}$ & $\begin{array}{l}8 \\
\dot{0} \\
\text { İ } \\
\stackrel{0}{0} \\
\dot{0}\end{array}$ & 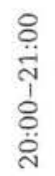 \\
\hline 0 & 100 & 60 & 90 & 100 & 65 & 50 & 65 & 80 & 80 & 100 & 100 & 100 & 80 & 60 \\
\hline 0.7 & 81 & 49 & 73 & 81 & 100 & 100 & 100 & 100 & 100 & 81 & 81 & 81 & 65 & 49 \\
\hline 1.5 & 63 & 38 & 57 & 63 & 81 & 100 & 100 & 81 & 81 & 63 & 63 & 63 & 50 & 38 \\
\hline 2.0 & 40 & 24 & 36 & 40 & 63 & 81 & 81 & 63 & 63 & 40 & 40 & 40 & 32 & 24 \\
\hline 3.5 & 19 & 11 & 17 & 19 & 40 & 63 & 63 & 40 & 40 & 19 & 19 & 19 & 15 & 11 \\
\hline 5.0 & 8 & 5 & 7 & 8 & 19 & 40 & 40 & 19 & 19 & 8 & 8 & 8 & 6 & 5 \\
\hline 10.0 & 1 & 1 & 1 & 1 & 8 & 19 & 19 & 8 & 8 & 1 & 1 & 1 & 1 & 1 \\
\hline 15.0 & 0 & 0 & 0 & 0 & 0 & 0 & 0 & 0 & 0 & 0 & 0 & 0 & 0 & 0 \\
\hline \multicolumn{2}{|c|}{ Irradiance $\left(\mu \mathrm{mol} \mathrm{s}^{-1} \mathrm{~m}^{-2}\right)$} & 125 & 310 & 500 & 750 & 800 & 750 & 700 & 700 & 600 & 550 & 400 & 225 & 100 \\
\hline
\end{tabular}

ethanol for $24 \mathrm{~h}$ and measured fluorometrically (Perkin Elmer LS-2B) (BMEPC 1988).

Hydrographical and chemical analysis. Temperature, fluorescence and conductivity were measured with a CTD-sonde (Mark V, Neil Brown) and salinity was computed from the data according to UNESCO (1981). Inorganic nutrients were determined with an autoanalyzer (Grasshoff et al. 1983), except for ammonia, which was determined manually (Grasshoff et al. 1983).

\section{RESULTS}

\section{Upper mixed water layer}

At the beginning of the study period, the cyanobacterial bloom was in a declining stage and total chl a concentration on 3 August at the frontal station (GR9) was $6.4 \mathrm{mg} \mathrm{m}^{-3}$; at the low-saline stations it was $7.2 \mathrm{mg}$ $\mathrm{m}^{-3}$ (GR8) and $6.5 \mathrm{mg} \mathrm{m}^{-3}$ (GR7). The clear spatial segregation of the 2 dominant cyanobacterial species, Nodularia spumigena and Aphanizomenon flos-aquae, observed in the earlier stage of the bloom, 2 wk before, had vanished and both species appeared over the whole entrance area of the Gulf (Kaisa Kononen, Finnish Inst. Mar. Res, unpubl.). A new bloom period (11 to 17 August) was initiated at the end of our cruise during a storm. The range of some parameters characterising the UML of the frontal and low-saline water masses are shown in Table 3.

Bacterioplankton numbers, the thymidine incorporation rate, numbers of heterotrophic flagellates and picocyanobacteria in the low-saline and frontal areas are shown in Figs. 3 to 6 and coefficients of variation in Table 4 , respectively.
Thymidine incorporation per cell was, on average, 1.3 times higher in the frontal water mass than in the low-saline water mass and the turnover time of bacterial numbers averaged $18 \mathrm{~d}$ (range 6 to $47 \mathrm{~d}$ ) in the low-saline water and $13 \mathrm{~d}$ (range 6 to $21 \mathrm{~d}$ ) in the frontal water. Changes in the turnover time of the bacterial numbers could have been used to distinguish the different water masses, but the response of the turnover time to disturbances was not immediate and was subject to a delay, e.g. due to the storm event on $2 \mathrm{~d}$. The average numbers of picocyanobacteria were also 1.3 times higher in the frontal water mass compared to the low-saline water mass. The average numbers of heterotrophic flagellates were almost the same in the low-saline water mass $\left(2.7 \times 10^{9}\right.$ cells m$\left.^{-3}\right)$ and in the frontal water mass $\left(2.6 \times 10^{9}\right.$ cells $\left.\mathrm{m}^{-3}\right)$. In the frontal samples, a significant positive correlation was found between numbers of bacterioplankton and heterotrophic flagellates $(r=0.68, p=0.03)$ and in the low-saline samples, a significant negative correlation existed between the numbers of picocyanobacteria and heterotrophic flagellates $(r=-0.72, p=0.02)$.

Table 3. Range of various parameters in frontal and low-saline samples. DIN: dissolved inorganic nitrogen. bd: below detection limit

\begin{tabular}{|lcc|}
\hline & Frontal & Low-saline \\
\hline Salinity $(\mathrm{ppt})$ & $6.13-6.64$ & $5.75-6.19$ \\
$\mathrm{PO}_{4}\left(\mathrm{mmol} \mathrm{m}^{-3}\right)$ & $\mathrm{bd}-0.05$ & $\mathrm{bd}-0.03$ \\
Total $\mathrm{P}\left(\mathrm{mmol} \mathrm{m}^{-3}\right)$ & $0.43-1.32$ & $0.47-2.20$ \\
$\mathrm{DIN}\left(\mathrm{mmol} \mathrm{m}^{-3}\right)$ & $0.08-1.64$ & $0.16-1.28$ \\
Total $\mathrm{N}\left(\mathrm{mmol} \mathrm{m}^{-3}\right)$ & $24-67$ & $25-70$ \\
Total chl a $\left(\mathrm{mg} \mathrm{m}^{-3}\right)$ & $3.7-12$ & $4.7-18$ \\
Primary production & $7-75$ & $7-49$ \\
$\left(\mathrm{mg} \mathrm{C} \mathrm{m}^{-3} \mathrm{~d}^{-1}\right)$ & & \\
\hline
\end{tabular}




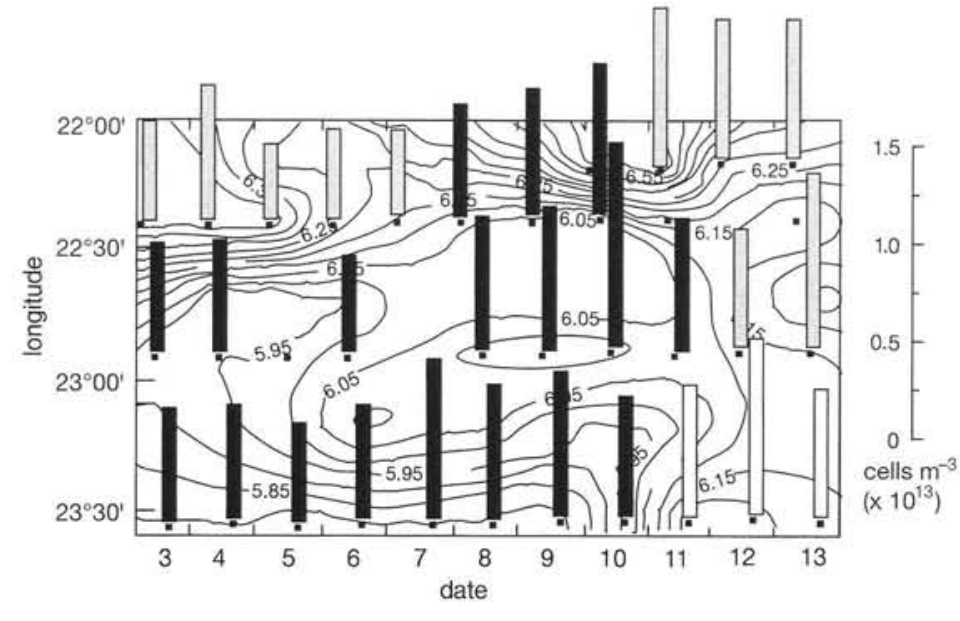

Fig. 3. Bacterial cell numbers (cells $\mathrm{m}^{-3}$ ) in the upper mixed water layer Black bars: low-saline stations; grey bars: frontal stations; white bars stations with water of unknown origin. The longitudes of the sampling stations are given on the $y$-axis (scale of space) and sampling dates in August 1992 are given on the $x$-axis (scale of time). The stations are denoted as black squares on the salinity isopleths (see also Fig. 1). Upper row: samples from GR9 ( 3 to 10 August) and GR10A (11 to 13 August); middle row: samples from GR8; lower row: samples from GR7

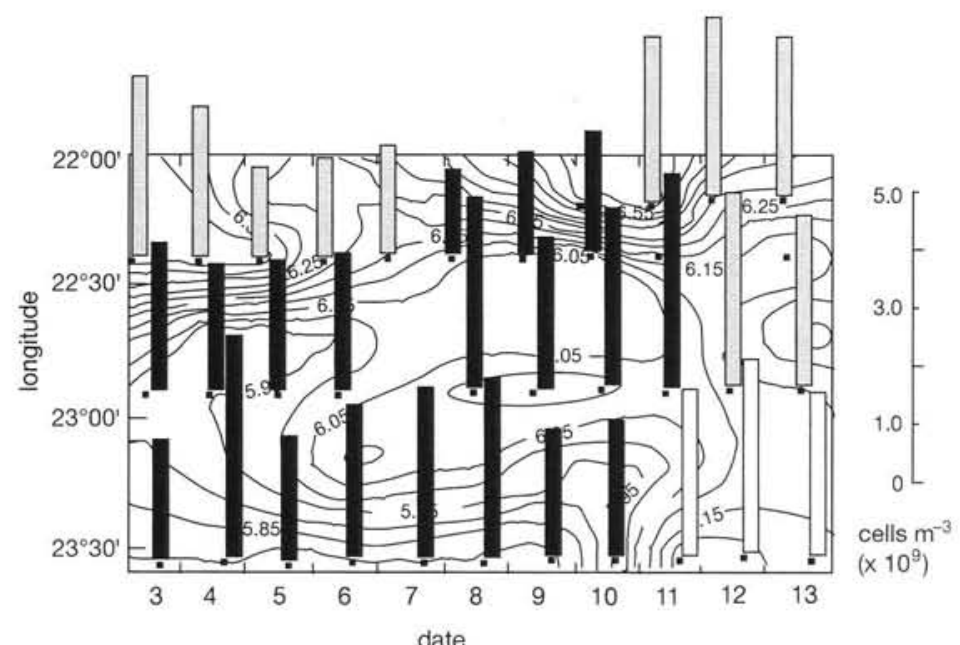

Fig. 5. Abundance of heterotrophic flagellates (cells $\mathrm{m}^{-3}$ ) in the upper mixed water layer. Symbols as in Fig. 3

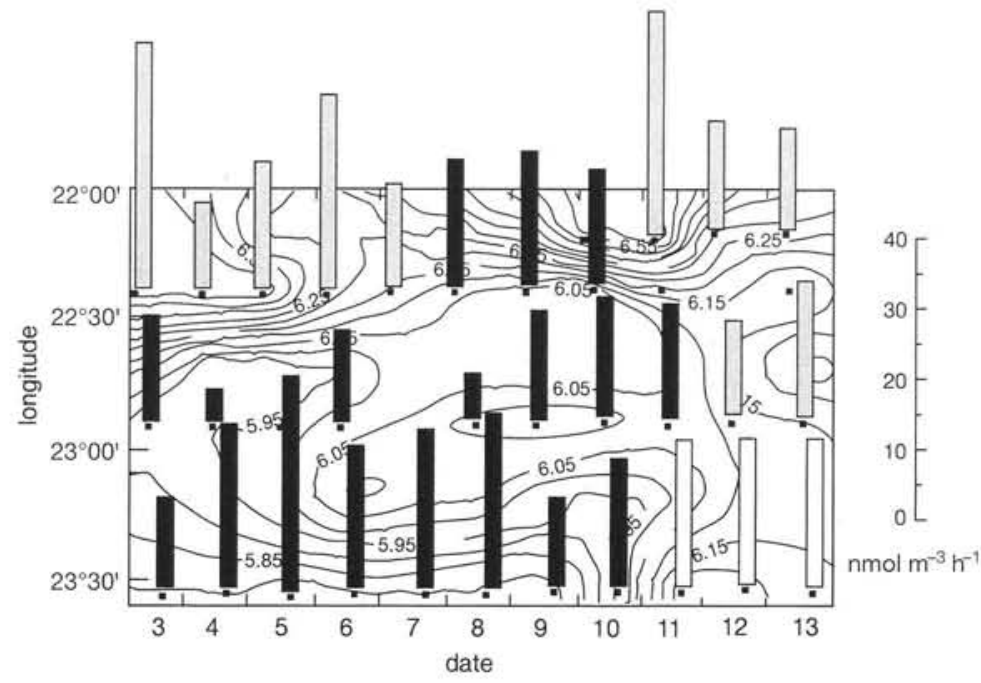

Fig. 4. Thymidine incorporation rate $\left(\mathrm{nmol} \mathrm{m}^{-3} \mathrm{~h}^{-1}\right)$ in the upper mixed water layer. Symbols as in Fig. 3

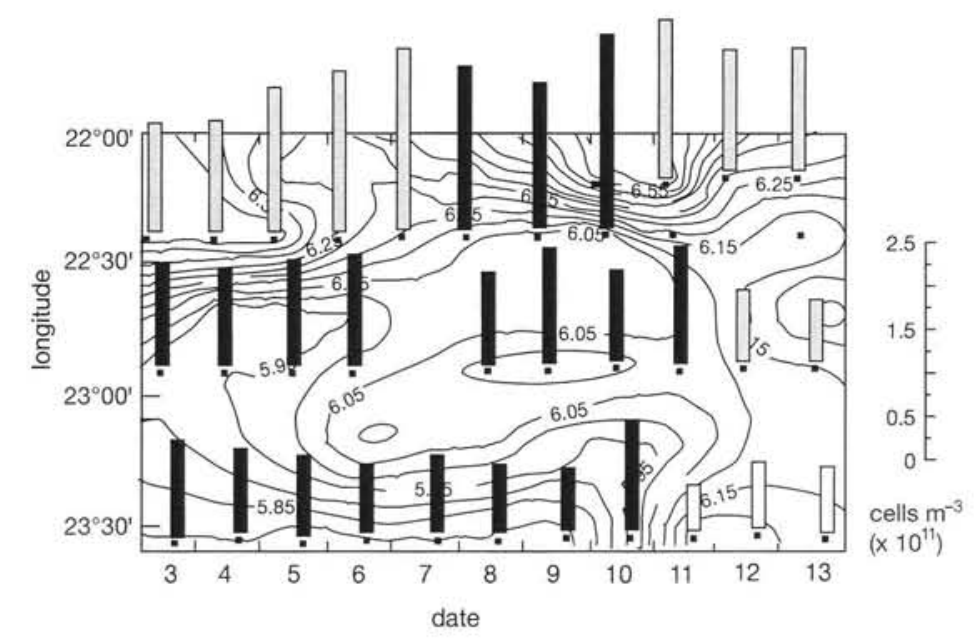

Fig. 6. Abundance of picocyanobacteria (cells $\mathrm{m}^{-3}$ ) in the upper mixed water layer. Symbols as in Fig. 3 
Table 4. Coefficient of variation (\%) of various parameters in frontal and low-saline water masses

\begin{tabular}{|lcc|}
\hline & Frontal & Low-saline \\
\hline Thymidine incorporation & 41 & 31 \\
Bacterial numbers & 27 & 25 \\
No. of heterotrophic flagellates & 25 & 25 \\
No. of picocyanobacteria & 31 & 29 \\
Phytoplankton primary production & 53 & 42 \\
\hline
\end{tabular}

Bacterial production (thymidine incorporation method) in the UML averaged $3.7 \mathrm{mg} \mathrm{C} \mathrm{m}^{-3} \mathrm{~d}^{-1}$ in the low-saline water and $4.5 \mathrm{mg} \mathrm{C} \mathrm{m}^{-3} \mathrm{~d}^{-1}$ in the frontal water during the study period. Bacterial production amounted to 4 to $44 \%$ of the primary production (average $16 \%$ ) in the low-saline water and to 4 to $41 \%$ of the primary production (average $15 \%$ ) in the frontal water. In the low-saline water, primary production and bacterial production showed a significant positive correlation $(\mathrm{r}=0.63, \mathrm{p}=0.05)$. Primary production varied more in the frontal water (CV $53 \%$ ) than in the low-saline water (CV $42 \%$ ).

The significant correlations of bacterioplankton, heterotrophic flagellates and picocyanobacteria with other measured parameters are shown in Table 5. The chl $a$ of the 2 to $20 \mu \mathrm{m}$ fraction was mainly found in Dinophysis acuminata and D. norvegica, Protoceratium reticulatum, Oocystis sp., and Nitzschia spp.

\section{Vertical profiles of bacterioplankton at Stns GR9 and GR10A}

In the UML, vertical profiles represented frontal water at the beginning and at the end of our study period and those in between, 8 to 10 August, represented the low-saline water mass (Table 2). Because the internal frontal interface did not vertically match

Table 5. Significant correlations of thymidine incorporation rate (TTI), numbers of heterotrophic flagellates (HF) and picocyanobacteria (PC) with other measured parameters in frontal (F) and low-saline (LS) stations. Bacterial numbers are excluded, because they showed no significant correlation. Aph.: Aphanizomenon flos-aquae; Nod.: Nodularia spumigena

\begin{tabular}{|c|c|c|c|c|c|c|c|}
\hline & & \multicolumn{2}{|c|}{ TTI } & \multicolumn{2}{|c|}{$\mathrm{HF}$} & \multicolumn{2}{|c|}{ PC } \\
\hline & & $\mathrm{r}$ & $\mathrm{p}$ & $\mathrm{r}$ & $\mathrm{p}$ & $\mathrm{r}$ & $\mathrm{p}$ \\
\hline Chl $a_{i}(2-20 \mu \mathrm{m})$ & F & 0.72 & 0.02 & & & & \\
\hline Aph biomass & $\mathrm{F}$ & 0.72 & 0.03 & & & & \\
\hline Salinity & LS & -0.49 & 0.04 & & & 0.53 & 0.02 \\
\hline Total P & LS & & & -0.48 & 0.04 & & \\
\hline Primary production & LS & 0.71 & 0.0009 & & & & \\
\hline Chl a (>20 $\mu \mathrm{m})$ & LS & & & & & 0.52 & 0.03 \\
\hline Nod. biomass & LS & & & & & 0.60 & 0.01 \\
\hline
\end{tabular}

with the surface front, the samples below the thermocline represented low-saline water from 3 to 10 August and frontal water from 11 to 13 August (see 'Materials and methods').

In the surface water ( $0 \mathrm{~m}$ samples), thymidine incorporation more than doubled after $2 \mathrm{~d}$ at the beginning of the study period, from 16 to $42 \mathrm{nmol} \mathrm{m}^{-3} \mathrm{~h}^{-1}$. When the low-saline water replaced the frontal water at Stn GR9, thymidine incorporation fell and ranged from 24 to $30 \mathrm{nmol} \mathrm{m}^{-3} \mathrm{~h}^{-1}$ ( 8 to 10 August). A storm began in the afternoon of 11 August and lasted until the evening of 12 August. Thymidine incorporation decreased during the storm from 37 to $15 \mathrm{nmol} \mathrm{m}^{-3} \mathrm{~h}^{-1}$. Below the thermocline, thymidine incorporation ranged from 3 to $10 \mathrm{nmol} \mathrm{m}{ }^{-3} \mathrm{~h}^{-1}$. The only exception was 6 August when higher values were measured (10 to $18 \mathrm{nmol} \mathrm{m}^{-3} \mathrm{~h}^{-1}$ ).

During the first $4 \mathrm{~d}$ of the cruise, leucine incorporation of the surface samples $(0 \mathrm{~m})$ was quite evenly distributed in the range of 171 to $239 \mathrm{nmol} \mathrm{m}^{-3} \mathrm{~h}^{-1}$ and then increased to $282 \mathrm{nmol} \mathrm{m}^{-3} \mathrm{~h}^{-1}$ ( 7 August). When there was low-saline water at the station (8 to 10 August), leucine incorporation was at a higher level (263 to $334 \mathrm{nmol} \mathrm{m}^{-3} \mathrm{~h}^{-1}$ ). The storm (11 August) caused leucine incorporation to diminish drastically ( $78 \mathrm{nmol} \mathrm{m} \mathrm{m}^{-3} \mathrm{~h}^{-1}, 12$ August). Below the thermocline, leucine incorporation was 1 order of magnitude less than above the thermocline.

In the surface samples of the frontal area, bacterial numbers ranged from 5 to $6 \times 10^{12}$ cells $\mathrm{m}^{-3}$ and just before the storm there was a maximum of $8 \times 10^{12}$ cells $\mathrm{m}^{-3}$ (11 August, Stn GR10A). In the low-saline samples ( 8 to 10 August), the numbers were slightly higher (the range was 6 to $10 \times 10^{12}$ cells $\mathrm{m}^{-3}$ ). Below the thermocline bacterial numbers ranged from 0.5 to $1.9 \times$ $10^{12}$ cells $\mathrm{m}^{-3}$. The turnover time of the bacterial numbers in the 0 and $20 \mathrm{~m}$ samples averaged $11 \mathrm{~d}$, in 40 , 60 and $90 \mathrm{~m}$ samples it was 8,7 and $8 \mathrm{~d}$, respectively. Thymidine incorporation per cell was greatest below the thermocline at $60 \mathrm{~m}$ depth and leucine incorporation per cell was greatest in the surface samples (Fig. 7).

The correlation coefficient of thymidine incorporation rate with leucine incorporation was 0.84 , and that of cell numbers was 0.73 $(\mathrm{n}=52)$. The average molar ratio (leucine incorporation to thymidine incorporation) was 7.7 ( $\mathrm{min} .4$, max. 15) above the thermocline and 3 (min. 1, max. 10) below the thermocline. The difference in leucine incorporation above and below the thermocline was larger 

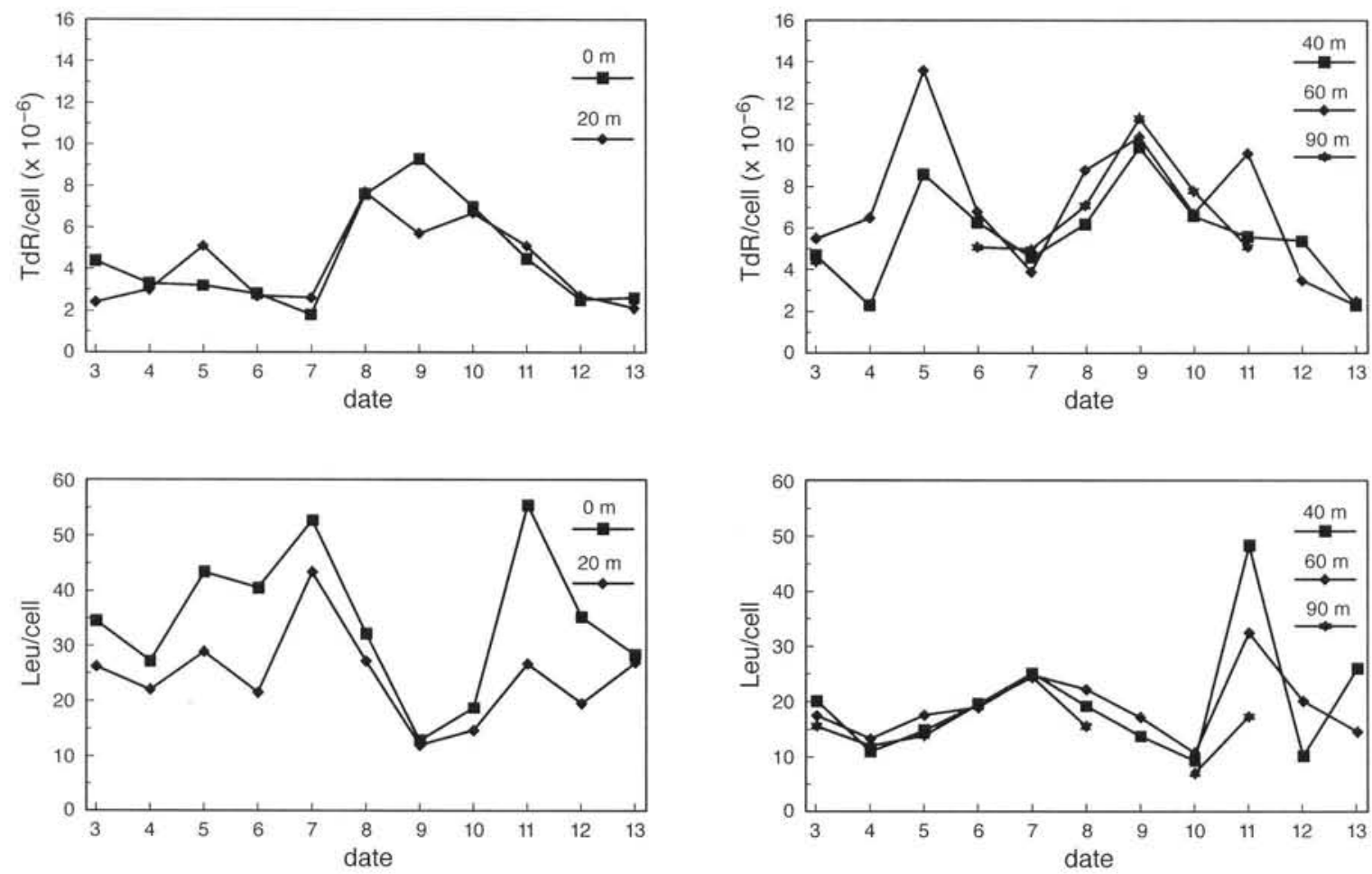

Fig. 7. Thymidine incorporation (TdR) per cell and leucine incorporation (Leu) per cell ( $\mathrm{nmol}$ cell $\left.{ }^{-1} \mathrm{~h}^{-1}\right)$ at the vertical sampling Stn GR9/GR10A

than in thymidine incorporation, 10 times compared to 4 times. In the surface water there were 2 clear peaks in the molar ratio, the first one at the beginning of the study period and the second one during the storm. The influence of the storm was also seen in the increased leucine:thymidine molar ratio of the deeper samples below the thermocline (Fig. 8).
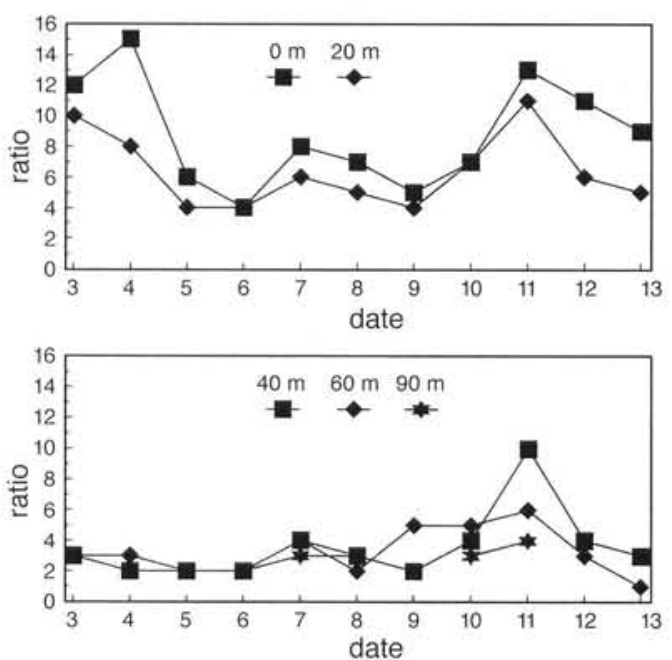

Fig. 8. Average molar ratio of leucine incorporation to thymidine incorporation the vertical sampling Stn GR9/GR10A
Areal bacterial production from the surface to $90 \mathrm{~m}$ depth was estimated based both on thymidine incorporation and on leucine incorporation. The average daily production was $232 \mathrm{mg} \mathrm{C} \mathrm{m}{ }^{-2}$ by the leucine incorporation method and $259 \mathrm{mg} \mathrm{C} \mathrm{m}^{-2}$ by the thymidine incorporation method. The profiles of bacterial production $\left(\mathrm{mg} \mathrm{C} \mathrm{m} \mathrm{m}^{-3} \mathrm{~h}^{-1}\right.$ ) obtained by the thymidine and leucine incorporation methods were similar $(\mathrm{r}=0.85, \mathrm{p}<0.0001)$. However, the daily areal production estimates from surface to $90 \mathrm{~m}$ depth obtained by the 2 methods were not correlated (Fig. 9).

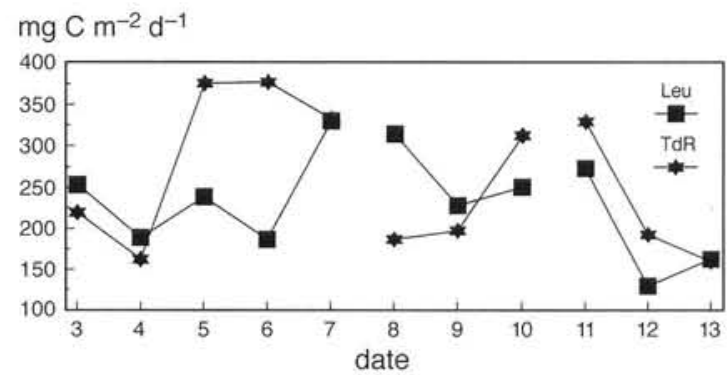

Fig. 9. Integrated bacterial production $\left(\mathrm{mg} \mathrm{C} \mathrm{m}^{-2} \mathrm{~d}^{-1}\right)$ at the vertical sampling Stn GR9/GR10A. Leu: leucine incorporation method, TdR: thymidine incorporation method 


\section{DISCUSSION}

\section{Patchiness in the study area}

The levels of bacterial numbers, bacterial production and primary production measured in this study were in the range measured earlier at the entrance of the Gulf of Finland during the late summer period (Grönlund \& Leppänen 1990, Heinänen \& Kuparinen 1991). The higher spatio-temporal resolution of our sampling compared to earlier studies did not result in the detection of unusually low or high production values, although it did reveal highly variable bacterial production. The distance between our sampling stations was about $40 \mathrm{~km}$, which was larger than the observed spatial scale of patches in phytoplankton biomass ( $\mathrm{chl}$ a) from 1 to over $10 \mathrm{~km}$. Phytoplankton is of great importance to heterotrophic bacterioplankton, because it is the main source of DOC in the open Baltic Sea (Maksimova 1982, Pocklington 1986). The scale of phytoplankton patches was smaller than the spatial resolution of our sampling and consequently resulted in high $\mathrm{CV}$ of thymidine incorporation between stations. A similar high CV of thymidine incorporation, as in the frontal water mass of our study, has been reported during highly patchy phytoplankton spring blooms (Kahru et al. 1990, Heinänen \& Kuparinen 1991, Kononen et al. 1992). Typical variation in summer, independent of the scale, would have been half of what we found (Heinänen \& Kuparinen 1991). Thus, physical fronts which coincided with cyanobacterial blooms created a water mass where bacterial production was more patchy than in the adjacent water masses. In contrast to production, the variation in bacterial numbers was very low.

\section{Frontal vs low-saline dynamics}

The enhanced levels of primary production, bacterial production and abundance, and abundance of picocyanobacteria in the frontal samples compared to those of the low-saline samples indicated that the frontal area provided ample growth conditions. Similar sites for enhanced biological activity compared to adjacent water masses have been recorded from the frontal areas of the North Sea and the English Channel (Holligan et al. 1984, van Duyl et al. 1990). The possible reasons for higher production might have been increased nutrient concentrations and higher turnover of nutrients and labile dissolved organic carbon compared to the low-saline water mass.

We expected bacterioplankton production to be a smaller proportion of primary production in the frontal area compared to the low-saline area since seasonal studies show that during the new production period, the microbial loop is less important than during the regenerated production period (Larsson \& Hagström 1982, Kuosa \& Kivi 1989, Lignell 1990). However, the relative production rates were about the same (16 in the low-saline area compared to 15 in the frontal area) and quite close to the average (20) found by Cole et al. (1988) in a cross-system overview. Thus, in both areas, bacterioplankton production had the same proportional importance, which indicated that the recorded frontal upwelling event did not drastically change the mode of production from regenerated to new production. The same relative production rates implied also that the availability of labile carbon originating from phytoplankton was perhaps the most important factor in determining the actual amount of bacterial production. A positive relationship existed between phytoplankton and cyanobacterial biomass and bacterial production in the frontal area, and phytoplankton primary production and bacterial production in the low-saline area (Table 5). This indicated that bacterial production in the frontal area was more connected with the already decaying cyanobacterial bloom than with the sites of highest primary production, as was the case in the low-saline area. In addition, the photosynthesis to respiration ratio $(\mathrm{P} / \mathrm{R})$ showed that the study area was net autotrophic and the low-saline area was even more net autotrophic than the frontal area (P/R 2.5 and 1.4, respectively; Jorma Kuparinen, Finnish Inst. Mar. Res., unpubl.). The significant correlation in the frontal area between bacterioplankton production and Aphanizomenon biomass also indicated the possibility that Aphanizomenon aggregates provided a rich substrate environment for effective bacterial recycling of inorganic nutrients.

The nutrient levels were almost equal in the frontal and low-saline samples. The only exception was total nitrogen concentrations, which were slightly higher in the frontal samples. The high ammonium concentrations in both areas suggested that effective decomposition of organic matter and regeneration of nutrients were occurring in the whole study area. These parallel the conclusion concerning bacterioplankton production and primary production, that the regenerated mode of production was the dominant feature in the study area. Because ammonium concentrations were quite high, it is probable that the rate of phosphate flux was limiting bacterioplankton growth (Kuparinen \& Heinänen 1993, Zweifel et al. 1993). At low phosphate concentrations, bacterioplankton cells are superior competitors compared to phytoplankton cells (Currie \& Kalff 1984a, b, Coveney \& Wetzel 1992. Güde et al. 1992, Rothhaupt \& Güde 1992) but, according to Rothhaupt \& Güde (1992), even very small phosphate pulses result in a shift of phosphate uptake from 
bacteria toward larger organisms. Although the regenerated mode of production was dominant, it is possible that occasional small or even large phosphate pulses to the surface layer below the thermocline provided a competitive advantage in phosphate uptake to phytoplankton in the frontal area. This could have been the major reason for enhanced primary production, which made the increase in bacterial production possible. In conclusion, although the massive cyanobacterial bloom formed by nitrogen fixing species was the most striking feature of the study area, it did not decrease the importance of regenerated production.

The control of bacterioplankton by grazers, mainly heterotrophic flagellates, has been shown in many studies in the Baltic Sea (Andersson et al. 1986, Kuosa \& Kivi 1989, Kuuppo-Leinikki 1990, Wikner et al. 1990, Wikner \& Hagström 1991). According to theories based on predator-prey dynamics (Fenchel 1982, 1986), variations in bacterial populations will be amplified in bacteriovores. Top-down control should also be particularly evident in out-of-phase oscillations between bacterial and bacteriovore abundance after a bloom period (Sorokin 1977, Sherr et al. 1982). In our study, this amplified variation was not detected, the variations in the numbers of heterotrophic flagellates and in the numbers of bacteria were approximately equal in the study area. Out-of-phase oscillations could not be detected either; instead, increases and decreases in the numbers of heterotrophic flagellates and bacterioplankton occurred almost identically (Figs. 2 \& 4). A similar observation has been made earlier in the frontal areas of the North Sea (van Duyl et al. 1990). Accordingly, top-down control of bacterioplankton by heterotrophic flagellates was not important in the frontal area and, even in the low-saline area, bottom-up control seemed to be more important over the time scale of this study. However, the positive relationship between bacterioplankton and heterotrophic flagellates seemed to imply that the increased bacterioplankton production was to the advantage of heterotrophic flagellates. On the other hand, the significant negative correlation between the numbers of heterotrophic flagellates and picocyanobacteria in the frontal area may indicate that flagellates grazed picocyanobacteria. In addition, the low variation in the numbers of heterotrophic flagellates suggested effective predation pressure on them.

\section{Bacterioplankton growth estimates and methodological considerations}

Estimation of bacterial production by thymidine and leucine incorporation methods are based on different processes, on DNA synthesis and on protein synthesis, respectively. If the rates of macromolecular syntheses are coupled (balanced growth), both methods should give similar production estimates (Kirchman et al. 1985, Chin-Leo \& Kirchman 1990). However, if there are shifts-up and shifts-down in the rates of bacterial assembly, the rates of DNA and protein syntheses become uncoupled and the production estimates by these methods may differ (Pritchard \& Tempest 1982, Chin-Leo \& Kirchman 1990).

Variations in the molar ratio between leucine and thymidine incorporation should reveal unbalanced growth (Chin-Leo \& Kirchman 1990). According to this reasoning there was a shift-down in the growth rate on 5 August (the ratio changed from 15 to 6 ), which could be detected down to $20 \mathrm{~m}$ depth and a shift-up during the storm on 11 August (ratio increased to 13). The disturbance caused by the storm could be seen as an increase in the molar ratio down to $60 \mathrm{~m}$ depth. This unbalanced growth may explain why bacterial production measured by thymidine incorporation and by leucine incorporation did not correlate in the upper mixed water layer on a volumetric basis in the whole water column or on an areal basis in contrast to many earlier studies (Fig. 9) (Chin-Leo \& Benner 1992, Kirchman 1992, Servais \& Lavandier 1993). However, the average production values for the whole study period obtained by the 2 methods were close. Thus our data suggest that the 2 methods do not give equivalent rates of bacterial production over the daily timescale in an environment which is subject to changes (Kirchman et al. 1985, Chin-Leo \& Kirchman 1990). However, they can still give quite similar estimates of production when averaged over longer spatial and temporal scales (Chin-Leo \& Kirchman 1990).

Although unbalanced growth might have been a very important factor resulting in the thymidine method giving higher production than the leucine method below the thermocline and vice versa above the thermocline, when the production estimates are considered, several uncertainties can be extracted from the methods. Firstly, we used a single factor for cell volume and cell carbon content to calculate production from the thymidine incorporation rates for the whole water column. Heinänen (1991) has shown that, in many parts of the Baltic Sea, cell volumes differ considerably above and below the thermocline during the summer season. The cell carbon content may also vary since Lee \& Fuhrman (1987) have shown that small cells have a higher carbon content than large cells. However, because cells below the thermocline are usually larger (Heinänen 1991), these 2 uncertainties may have partly compensated for each other. Secondly, the discrepancy between the estimates given by the 2 methods may have been due to using an incorrect conversion factor to convert the thymidine incorporation rate to cell production. We used a conservative 


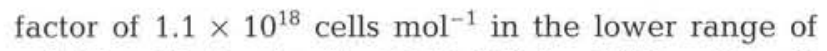
published factors for the Gulf of Finland (Kuparinen \& Kuosa 1993). The same factor was used in all samples. To our knowledge, there are no published conversion factors derived from the water layers below the thermocline in the Baltic Sea and, even in other sea areas, most conversion factor experiments are performed using surface water. Thus it was difficult to determine whether different conversion factors should have been used for the samples below the thermocline.

The turnover rates of bacterial numbers (calculation based on thymidine method and cell abundance) were greater in the samples below the thermocline than in the UML. This seemed to be unrealistic and indicated that the conversion factor was too high for the bacterioplankton in the deeper layers or too low for the bacterioplankton in the UML. In addition, according to the molar ratios, the growth of bacterioplankton below the thermocline seemed to be balanced and the 2 methods should have given similar production estimates in this water layer. If we had chosen a higher conversion factor to be used for the UML samples and a lower one for the samples below the thermocline, the areal estimates of bacterial production calculated from the thymidine and leucine methods would have shown a better correlation. However, when this matter was investigated thoroughly, it became clear that thymidine incorporation per cell (a parameter not influenced by a conversion factor) was highest at $60 \mathrm{~m}$ depth and was also higher at 40 and $90 \mathrm{~m}$ depth than in the UML. This implied that a higher, rather than lower, conversion factor should have been used for thymidine incorporation below the thermocline than in the UML. This can only be explained by the sedimenting bloom providing good growth conditions for heterotrophic bacteria below the thermocline allowing them to multiply vigorously. It is concluded that estimates of bacterial production in deep, multilayer seas may be strongly biased, if conversion factors from the surface water are used throughout the water column and efforts should be made to determine conversion factors in other than the surface water layer.

We performed saturation level experiments in different water parcels which indicated that the saturation level was lower than the concentration of leucine we used for incorporation measurements and, hence, that isotope dilution did not occur. However, saturation levels were not checked from every sample and the kinetic approach was not used in the leucine incorporation measurements as recommended by van Looij \& Riemann (1993) and thus there is a small possibility that occasionally we might have used levels of leucine below the saturating concentration. Because no dilution factor was used, the leucine incorporation-based production estimates are conservative.
In spite of these methodological problems, the trend of leucine incorporation-based production being higher in the UML and thymidine incorporation-based production higher below the thermocline indicated that bacterial growth in the UML was primarily to increase biomass by increasing biovolume and below the thermocline to increase biomass by increasing the number of cells. This is opposite to the usual late summer situation, when the cells are generally numerous but very small in the UML and relatively few but large in size below the thermocline (Heinänen 1991). This episode was made possible in the UML by decreased grazing pressure on bacterioplankton, which is usually highest on largest cells, and by decaying bloom providing nutrients; and in the water layers below the thermocline by the sedimenting bloom. Thus the frontal activity markedly changed bacterioplankton growth patterns, although it did not change the relative importance of regenerated production.

Acknowledgements. We thank the Finnish Institute of Marine Research, the Academy of Finland, and the Maj and Tor Nessling Foundation for funding this study. The analysis of water masses was done by Sulev Nômmann, Juss Pavelson and Jaan Laanemets from the Estonian Marine Institute. Finally, we greatly appreciate the shipboard and laboratory assistance of Maija Huttunen, Markku Jansson, Timo Laitinen, Pirkko Lemponen, Terttu Someroja, Pirjo Tikkanen and Tuovi Vartio.

\section{LITERATURE CITED}

Andersson, A., Larsson, U., Hagström, A. (1986). Sizeselective grazing by a microflagellate on pelagic bacteria. Mar. Ecol. Prog. Ser. 33: 51-57

Autio, R. M. (1990). Bacterioplankton in filtered brackish water cultures: some physical and chemical parameters affecting community properties. Arch. Hydrobiol. 117: $437-451$

Azam, F., Fenchel, T., Field, J. G., Gray, J. S., Meyer-Reil, L. A., Thingstad, F. (1983). The ecological role of water-column microbes in the sea. Mar. Ecol. Prog. Ser. 10: 257-263

BMEPC (1988). Guidelines for the Baltic monitoring programme for the third stage. Baltic Sea Environment Proceedings No. 27D Baltic Marine Environment Protection Commission, Helsinki

Bjørnsen, B. K. (1986). Automatic determination of bacterioplankton biomass by image analysis. Appl. environ. Microbiol. 51: 1199-1204

Chin-Leo, G., Benner, R. (1992). Enhanced bacterioplankton production and respiration at intermediate salinities in the Mississippi River plume. Mar. Ecol. Prog. Ser. 87: 87-103

Chin-Leo, G., Kirchman, D. L. (1990). Unbalanced growth in natural assemblages of marine bacterioplankton. Mar. Ecol. Prog. Ser. 63:1-8

Cole, J. J., Findlay, S., Pace, M. L. (1988). Bacterial production in fresh and saltwater ecosystems: a cross-system overview. Mar. Ecol. Prog. Ser. 43: 1-10

Coveney, M. F., Wetzel, R. G. (1992). Effects of nutrients on specific growth rate of bacterioplankton in oligotrophic lake water cultures. Appl, environ. Microbiol. 58: 150-156 
Currie, D. J., Kalff, J. (1984a). A comparison of the abilities of freshwater algae and bacteria to acquire and retain phosphorus. Limnol. Oceanogr. 29: 298-310

Currie, D. J. Kalff, J. (1984b). The relative importance of bacterioplankton and phytoplankton in phosphorus uptake in freshwater. Limnol. Oceanogr. 29: 311-321

Dugdale, R. C., Goering, J. J. (1967). Uptake of new and regenerated forms of nitrogen in primary productivity. Limnol. Oceanogr. 12: 196-206

Fenchel, T. (1982). Ecology of heterotrophic microflagellates IV. Quantitative occurrence and importance as bacterial consumers. Mar. Ecol. Prog. Ser. 9: 35-42

Fenchel, T. (1986). The ecology of heterotrophic microflagellates. Adv, microb. Ecol. 9: 57-97

Fuhrman, J. A., Azam, F. (1982). Thymidine incorporation as a measure of heterotrophic bacterioplankton production in marine surface waters: evaluation and field results. Mar. Biol. 66: 109-120

Goldman, J. C., Caron, D. A., Dennett, M. R. (1987). Regulation of gross growth efficiency and ammonium regeneration in bacteria by substrate C:N ratio. Limnol. Oceanogr. 32: $1239-1252$

Grasshoff, K., Ehrhardt, M., Kremling, K. (1983). Methods of seawater analysis, 2nd edn. Verlag Chemie, Weinheim

Grönlund, L., Leppänen, J.-M. (1990). Long-term changes in the nutrient reserves and pelagic production in the western Gulf of Finland. Finn. mar. Res. 257: 15-27

Güde, H., Rothhaupt, K. O., Siuda, W. (1992). Impact of dissolved organic phosphorus on the competition for phosphorus between algae and bacteria in Lake Constance. Arch. Hydrobiol. Beih. Ergebn. Limnol. 37: 121-128

Haas, L. W. (1982). Improved epifluorescence microscopy for observing planktonic micro-organisms. Annls Inst. océanogr. Paris 58 (Suppl.): 261-266

Heinänen, A. (1991). Bacterial numbers, biomass and productivity in the Baltic Sea: a cruise study. Mar. Ecol. Prog. Ser. 70: $283-290$

Heinänen, A. (1993). Measuring thymidine incorporation in the open Baltic Sea, a temperate brackish water estuary: comments on saturation level of thymidine. Arch. Hydrobiol. 127: 289-298

Heinänen, A., Kuparinen, J. (1991). Horizontal variation of bacterioplankton in the Baltic Sea. Appl. environ. Microbiol. 57:3150-3155

Hobbie, J. E., Daley, R. J., Jasper, J. (1977). Use of Nuclepore filters for counting bacteria by fluorescence microscopy. Appl, environ. Microbiol. 33: 1225-1228

Holligan, P. M., Harris, R. P., Newell, R. C., Harbour, D. S., Head, R. N., Linley, E. A. S., Lucas, M. I., Tranter, P. R. G., Weekley, C. M. (1984). Vertical distribution and partitioning of organic carbon in mixed, frontal and stratified waters of the English Channel. Mar. Ecol. Prog. Ser. 14: $111-127$

Hällfors, G., Niemi, A. (1986). Views on the use of phytoplankton as a parameter in monitoring the state of the Baltic Sea. In: Baltic Marine Environment Protection Commission Helsinki Commission. Baltic Sea Monitoring Symposium. Baltic Sea Environment Proceedings 19: 246-258

Kahru, M., Nômmann, S., Simm, M., Vilbaste, K. (1986). Plankton distributions and processes in the Baltic boundary zones. In: Nihoul, J. C. J. (ed.) Marine interfaces ecohydrodynamics. Elsevier, Amsterdam, p. 273-293

Kahru, M., Leppänen, J.-M., Nômmann, S., Passow, U., Postel, L., Schultz, S. (1990). Spatio-temporal mosaic of the phytoplankton spring bloom in the open Baltic Sea in 1986. Mar. Ecol. Prog. Ser. 66: 301-309

Kiørboe, T. (1993). Turbulence, phytoplankton cell size, and the structure of pelagic food webs. Adv, mar. Biol. 29: 1-72 Kirchman, D. L. (1992). Incorporation of thymidine and leucine in the subarctic Pacific: application to estimating bacterial production. Mar. Ecol. Prog. Ser. 82: 301-309

Kirchman, D. L., Keil, R. G., Wheeler, P. A. (1990). Carbon limitation of ammonium uptake by heterotrophic bacteria in the subarctic Pacific. Limnol. Oceanogr. 35: 1258-1266

Kirchman, D. L., K'nees, E., Hodson, R. E. (1985). Leucine incorporation and its potential as a measure of protein synthesis by bacteria in natural aquatic systems. Appl. environ. Microbiol. 49: 599-607

Kirchman, D. L., Newell, S. Y., Hodson, R. E. (1986). Incorporation versus biosynthesis of leucine: implications for measuring rates of protein synthesis and biomass production by bacteria in marine systems. Mar. Ecol. Prog. Ser. 32: $47-59$

Kivi, K., Kaitala, S., Kuosa, H., Kuparinen, J., Leskinen, E., Lignell, R., Marcussen, B., Tamminen, T. (1993). Nutrient limitation and grazing control of the Baltic plankton community during annual succession. Limnol. Oceanogr. 38: 893-905

Kononen, K., Nômmann, S. (1992). Spatio-temporal dynamics of the cyanobacterial blooms in the Gulf of Finland. In: Carpenter, E. J., Capone, D., Reuter, J. (eds.) Marine pelagic cyanobacteria: Trichodesmium and other diazotrophs. NATO ASI Ser, C, Ÿno. 362. Kluwer, Dordrecht, p. 95-114

Kononen, K., Nômmann, S., Hansen, G., Hansen, R., Breuel, G., Gupalo, E. (1992). Spatial heterogeneity and dynamics of vernal phytoplankton species in the Baltic Sea in April-May 1986. J. Plankton Res. 14: 107-125

Krauss, W. (1981). The erosion of a thermocline. J. phys. Oceanogr. 11: 415-433

Kuosa, H., Kivi, K. (1989). Bacteria and heterotrophic flagellates in the pelagic carbon cycle in the northern Baltic Sea. Mar. Ecol. Prog. Ser. 53: 93-100

Kuparinen, J., Heinänen, A. (1993). Inorganic nutrient and carbon controlled bacterioplankton growth in the Baltic Sea. Estuar. coast. Shelf Sci. 37: 271-285

Kuparinen, J., Kuosa, H. (1993). Autotrophic and heterotrophic picoplankton in the Baltic Sea. Adv. mar. Biol. 29 73-128

Kuuppo-Leinikki, P. (1990). Protozoan grazing on planktonic bacteria and its impact on bacterial population. Mar. Ecol. Prog. Ser. 63: 227-238

Larsson, U., Hagström, Å. (1982). Fractionated phytoplankton primary production, exudate release and bacterial production in a Baltic eutrophication gradient. Mar. Biol. 67: $57-70$

Lee, S., Fuhrman, J. A. (1987). Relationships between biovolume and biomass of naturally derived marine bacterioplankton. Appl. environ. Microbiol. 53: 1298-1303

Leppänen, J.-M. (1988). Cycling of organic matter during the vernal growth period in the open northern Baltic Proper. VI. Sinking of particulate matter. Finn. mar. Res. 255: $97-118$

Lignell, R. (1990). Excretion of organic carbon by phytoplankton: its relation to algal biomass, primary productivity and bacterial secondary productivity in the Baltic Sea. Mar. Ecol. Prog. Ser. 68: 85-99

Lignell, R., Heiskanen, A.-S., Kuosa, H., Gundersen, K., Kuuppo-Leinikki, P., Pajuniemi, R., Uitto, A. (1993). Fate of a phytoplankton spring bloom: sedimentation and carbon flow in the planktonic food web in the northern Baltic. Mar. Ecol. Prog. Ser. 94: 239-252

Maksimova, M. P. (1982). The balance of nutrients and organic matter in the Baltic Sea during the period of inten- 
sive anthropogenic action. Oceanol. Acad. Sci. U.S.S.R. 22: 555-559

Mälkki, P., Tamsalu, R. (1985). Physical features of the Baltic Sea. Finn. mar. Res. 252: 1-110

McManus, G. B., Fuhrman, J. A. (1988). Control of marine bacterioplankton populations: measurement and significance of grazing. Hydrobiologia 159: 51-62

Nielsen, G. A., Bresta, A.-M. (1984). Guidelines for the measurement of phytoplankton primary production, 2nd edn. The Baltic Marine Biologists Publ. No. 1. Marine Pollution Laboratory, Charlottenlund

Nômmann, S. (1990). Physical control of phytoplankton growth in the Baltic Sea. A multitude of spatio-temporal scales. Ph.D. thesis, Dept. Systems Ecol, University of Stockholm

Nômmann, S., Kaasik, E. (1992). Hydrodynamical control of phytoplankton succession during the vernal light-limited phase in the Baltic Sea. Mar. Ecol. Prog. Ser. 84: 279-292

Pocklington, R. (1986). The Gulf of St. Lawrence and the Baltic Sea: two different organic systems. Dtsch. hydrogr. Z. 39: $65-75$

Pritchard, R. H., Tempest, D. W. (1982). Growth: cells and populations. In: Mandelstam, J. McQuillen, K., Dawes, I. (eds.) Biochemistry of bacterial growth, 3rd edn. Blackwell Scientific Publications, Oxford, p. 99-123

Riemann, B., Bjørnsen, B. K., Newell, S., Fallon, R. (1987). Calculation of cell production of coastal marine bacteria based on measured incorporation of $\left({ }^{3} \mathrm{H}\right)$ thymidine. Limnol. Oceanogr. 32: 471-476

Rothhaupt, K. O., Güde, H. (1992). The influence of spatial and temporal concentrations gradients on phosphate partitioning between different size fractions of plankton: further evidence and possible causes. Limnol. Oceanogr. 37: 739-749

Servais, P. Lavandier, P. (1993). Consistency between bacterial productions estimated from ${ }^{3} \mathrm{H}$-thymidine and ${ }^{3} \mathrm{H}$ leucine incorporation rates in natural freshwaters. C.r. Acad. Sci., Paris, Sér. 3, 316: 642-646

Sherr, B. F., Sherr, E. B., Berman, T. (1982). Decomposition of organic detritus: a selective role for microflagellate proto-

This article was submitted to the editor zoa. Limnol. Oceanogr. 27: 765-769

Shiah, F.-K., Ducklow, H. W. (1994). Temperature and substrate regulation of bacterial abundance, production and specific growth rate in Chesapeake Bay, USA. Mar. Ecol. Prog. Ser. 103: 297-308

Simon, M., Azam, F. (1989). Protein content and protein synthesis rate of planktonic marine bacteria. Mar. Ecol. Prog. Ser. 51: 201-213

Sorokin, Y. I. (1977). The heterotrophic phase of plankton succession in the Japan Sea. Mar. Biol. 41: 107-117

Stigebrandt, A., Wulff, F. (1987). A model for the dynamics of nutrients and oxygen in the Baltic Proper. J. mar. Res. 45: 729-759

UNESCO (1981). Background papers and supporting data on the practical salinity scale 1978 . UNESCO Tech. Pap. Mar. Sci. 37: 1-44

van Duyl, F. C., Bak, R. P. M., Kop, A. J., Nieuweland, G. (1990). Bacteria, auto- and heterotrophic nanoflagellates, and their relations in mixed, frontal and stratified waters of the North Sea. Neth. J. Sea Res. 26: 97-109

van Looij, A., Riemann, B. (1993). Measurements of bacterial production in coastal marine environments using leucine: application of a kinetic approach to correct for isotope dilution. Mar. Ecol. Prog. Ser. 102: 97-104

Wikner, J., Hagström, А.. (1991). Annual study of bacterioplankton community dynamics. Limnol. Oceanogr. 36: 1313-1324

Wikner, J., Rassoulzadegan, F., Hagström, A. (1990). Periodic bacterivore activity balances bacterial growth in the marine environment. Limnol. Oceanogr. 35: 313-324

Williams, P. J. leB. (1981). Incorporation of microheterotrophic processes into the classical paradigm of the planktonic food web. Kieler Meeresforsch. Sonderh. 5: 1-28

Wright, R. T., Coffin, R. B. (1984). Measuring microzooplankton grazing on planktonic marine bacteria by its impact on bacterial production. Microb. Ecol. 10: 137-149

Zweifel, U. L., Norrman, B., Hagström, Å. (1993). Consumption of dissolved organic carbon by marine bacteria and demand for inorganic nutrients. Mar. Ecol. Prog. Ser. 101: $23-32$

Manuscript first received: April 26, 1994

Revised version accepted: September 16, 1994 